\title{
歯周病患者血清中の総ハイドロオキシプロリン量について
}

\author{
穴村紳一内田武志白根忠 \\ 秀衡泰子小保田みどり岡本 莫 \\ 広島大学歯学部歯科保存学第 2 講座 \\ (主任 : 岡本 莫教授) \\ (昭和 54 年 2 月 27 日受付)
}

\section{Total Hydroxyproline Levels in Sera of Patients with Periodontal Disease}

\author{
Shinichi ANAMURA, Takeshi UCHIDA, Tadashi SHIRANE, \\ Yasuko HIDEHIRA, Midori KUBOTA and Hiroshi OKAMOTO \\ Department of Endodontology and Periodontology, \\ Hiroshima University School of Dentistry \\ (Director: Prof. Hiroshi OKAMOTO)
}

Measurements of total hydroxyproline levels in human sera were carried out on 11 clinical healthy subjects ranging from 23 to 27 years of age, and in 57 patients with periodontal disease ranging from 16 to 64 years of age.

The correlations between hydroxyproline levels and a few indicies of periodontal disease were discussed in order to estimate hydroxyproline levels as an index of periodontal tissue destruction.

The following results were obtained.

1. Hydroxyproline levels in sera were constant regardless of age group.

2. Hydroxyproline levels in sera of patients were higher than the levels of clinical healthy subjects. But there was no significant difference in them.

3. No significant correlations were found out between indices of periodontal disease, i.e. Gingival Bone counts, Gingival scores, Bone scores and Salivary leucocyte counts, and total hydroxyproline levels in sera. But there was seen a significant correlation only between Bone scores and hydroxyproline levels in sera of clinical healthy subjects.

Some factors concerning hydroxyproline levels in sera are to be studied.

\section{I. 緒 言}

歯周病の診断, 治療効果の判定のため種々の指数 ${ }^{1 \sim 4)}$

本研究の一部は昭和 52 年度文部省科学研究費 (No. 277561) によった。

本論文の要旨は昭和 52 年 5 月第 20 回春季日本歯周病学会 （新潟）において発表した。
が用いられているが,これらは再現性, 定量性, 客観性 において不十分なものが多い。そこで著者らは歯周病診 断の客観的指標の開発を目的として, 歯周組織の炎症の 評価法として唾液中白血球数 ${ }^{5}$, 歯周病の感染の評価法 として末梢血白血球の NBT 還元率の利用6などについ て報告した。

歯周組織, 特にその主たる構成成分であるコラーゲン の破壊の程度を臨床的に評価することができれば，歯周 
表 1 Variation with age of serum hydroxyproline

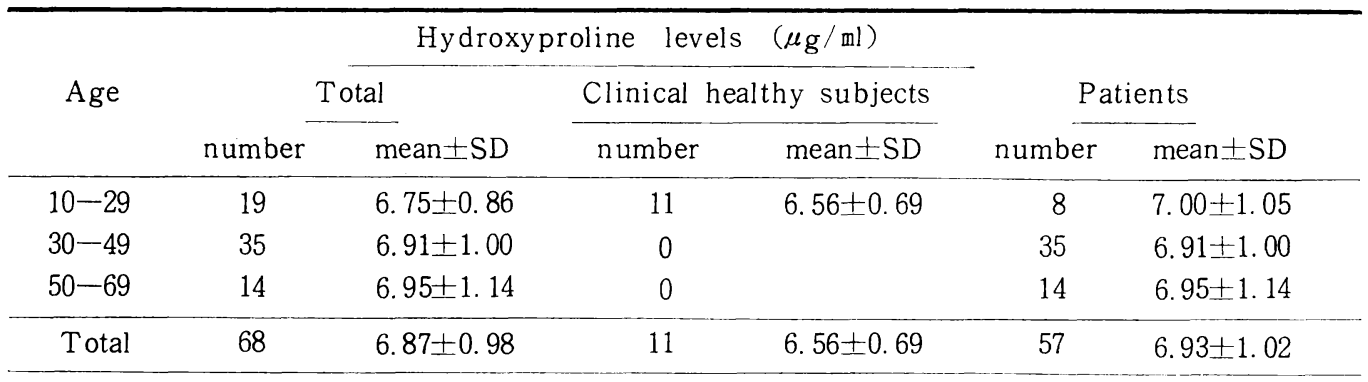

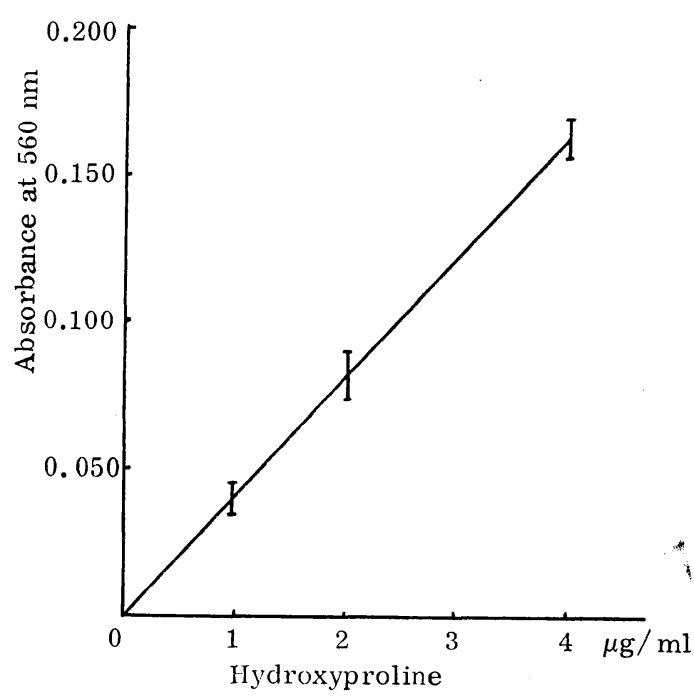

図 1 Absorbance of the chromophore obtained from the hydroxyproline product

病の診断に大いに役立つはずである。Prockop, Kivirikko ら 7 10)によると，コラーゲンの分解に伴ってコラ ーゲンに特異なアミノ酸であるハイドロオキシプロリン （以下ハイプロと略記）が血中，尿中へ遊離する。プロ リンは直接水酸化されハイプロになることはなく，必ず コラーゲン分子に合成された後水酸化されることから， 血中及び㽷中のハイプロ量はコラーゲンの分解産物と考 えることができる。すなわち，コラーゲンの合成量が安 定している状態においては，血中あるいは尿中のハイプ 口量を測定することによりコラーゲンの分解量を知るこ とができるとしている。実際, 骨破壊を伴う疾患や結合 組織の代謝異常疾患では，血中のハイプロ量や尿中への ハイプロ排泄量が増加することが確かめられ，ハイプロ 量の変化がこれらの疾患の重要な診断法となり得ること が報告されている7 14)。また Paunio ${ }^{15)}$ は歯肉溝滲出液 中のハイプロ量を定量し, そのハイプロ含有物は歯肉溝
へ漏出した血清中成分, 及び血漿蛋白分解酵素による歯 肉コラーゲンの分解産物から由来すると考察している。 さらに原ら ${ }^{16)}$ は外科療法を施した際の歯周ポケット滲出 液及び血清中ハイプロ含量の変動を調べ，その結果滲出 液中のハイプロ量は血清中のそれと類似した動態を示 し, 滲出液ハイプロ含有物質は, 歯肉コラーゲンから由 来するのみでなく，一部は血清からも由来するとと考察 している。

本研究は, 歯周病患者血液を資料として, その総ハイ プロ量を定量し，歯周病の診断的価值を検討することを 目的とした。

\section{II. 材料と方法}

検査対策 : 広島大学歯学部附属病院歯周病診療室を訪 れた患者のうち, 間診により歯周病及びう蝕以外には全 身的に健康なことを確かめた 16〜64 歳の男 19 名. 女 38 名の計 57 名を被験者とした。なお, 全身及び歯周組織 の臨床的健康な歯学部学生 $23 \sim 27$ 歳の男 8 名, 女 3 名 の計 11 名を対照とした。被験者の口腔内詮查及びX線 診査を行なうと同時に, 肘正中静脈より採血, 血清を分 離し，用時まで涷結保存した。

ハイプロ定量 : Kivirikko ら ${ }^{17,18)}$ の方法により血清中 総ハイプロ量を定量した。すなわち, 被験血清を $6 \mathrm{~N}$ 塩 酸中で $121^{\circ} \mathrm{C} 15$ 時間加水分解し, 固形物を孔径 $5 \mu \mathrm{m}$ のミリポアファフィルター（ミリポア USA）で除去後 $\mathrm{pH} 8.7$ に調整し遊離のハイプロを合わせピロールへ酸 化し, エーリッヒ試薬と反応させ $560 \mathrm{~nm}$ で比色定量し た。

歯周病の評価 : 歯周病変の進行程度は被験者の口腔内 診査, およびレントゲン診查を行ないD Dunning と Leach $^{19)}$ の Gingval score, Bone score, 及び GingivalBone count により評価した。また Klinkhamer ら 20 ) の提唱した混合唾液中の白血球数を改良した簡便法 ${ }^{5)}$, 


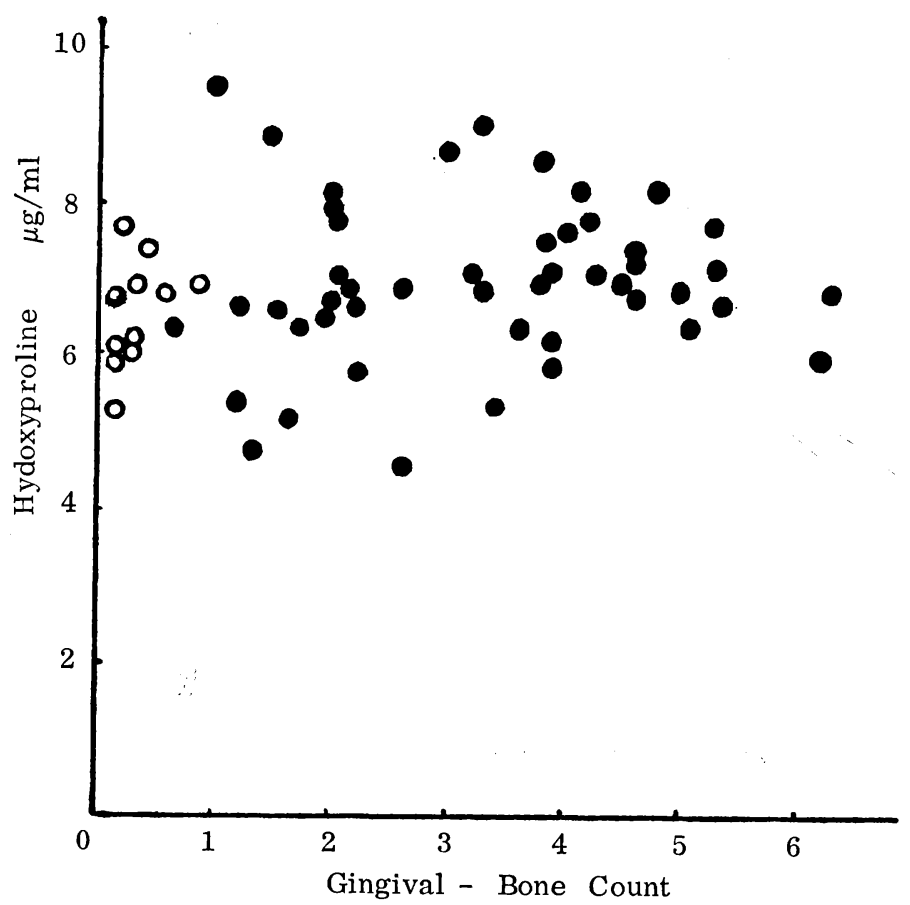

図 2 Correlation between hydroxyproline levels in sera and gingival-bone count

Patients with periodontal disease

Clinical healthy subjects

すなわち $5 \mathrm{ml}$ の $1.2 \%$ 食塩水で 1 分間閉口含嗽した 含嗽液中の白血球数を計算し，比較対照とした。

なおこれらと血清中総ハイプロ量との間の相関係数か ら, 統計学的にその有意性を検討した。

\section{III. 結 果}

1. 血清中総ハイプロ量

既知濃度のハイプロ 0〜4 $\mu \mathrm{g} / \mathrm{ml}$ は， $560 \mathrm{~nm}$ の吸光 度との間に図 1 の様に直線関係の得られることを確認し た。

被験者の年齢によって分類した血清中総ハイプロ量を 表 1 に示した。統計処理を行なったところいずれの年齢 群の平均値の間にも有意の差はなかった。

また健康者群と患者群の平均值を比較したところ，そ れぞれ $6.56 \mu \mathrm{g} / \mathrm{ml}, 6.93 \mu \mathrm{g} / \mathrm{ml}$ とわずかに患者群の方 が高い值を示したものの, 有意の差は認められなかっ た。
2. 血清中総ハイプロ量と歯周病症状

1）ハイプロ量と Gingival-Bone count

図 2 , 表 2 に示す様に血清中ハイプロ量と GingivalBone count との間には有意の相関関係は認められなか った。次いで Gingival Bone count を Gingival score と Bone score に分けて検討してみた。Gingival score, すなわち歯肉の炎症とハイプロ量との間の関係を図 3 , 表 2 に, Bone score, すなわち歯槽骨破壊の結果とハイ プロ量との間の関係を図 4 , 表 2 に示した。被験者全体 においては，いずれの関係においても有意の相関関係は 認められなかった。

健康者群と患者群に分けて検討してみると, 健康者群 においての Bone score とハイプロ量の間にのみ有意の 相関関係が認められた $(\mathrm{p}<0.02)$ 。

2）ハイプロ量と唾液中白血球数

図 5 , 表 2 に示す様に血清中ハイプロ量と唾液中白血 球数との間の相関係数は, 低く $(r=0.12)$ 有意の相関関 係はなかった。 


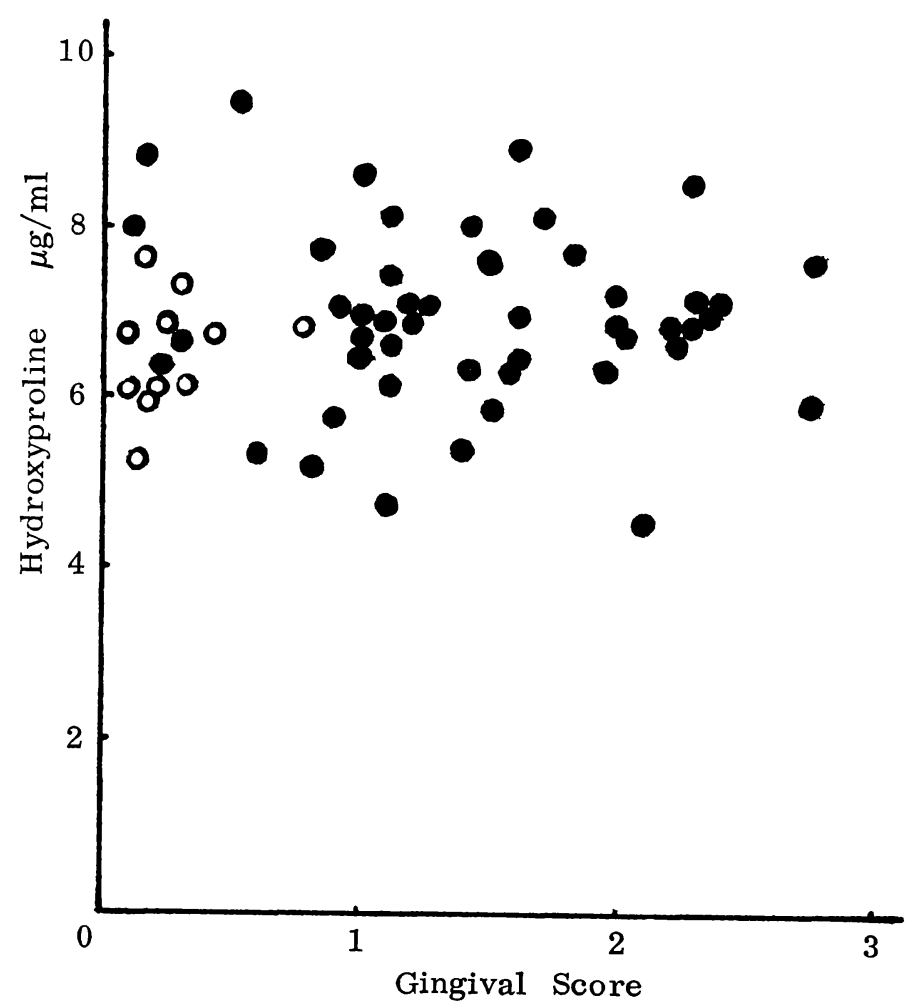

図 3 Correlation between hydroxyproline levels in sera and gingival-bone count

- Patients with periodontal disease

$\bigcirc$ Clinical healthy subjects

\section{VI. 考察}

組織ハイプロが殆ど体内のコラーゲンに由来しこの分 解の結果, 大半はペプチドの形で一部は遊離のハイプロ として血中を経て尿中へ排泄される。そのため血中又は 尿中の総ハイプロ量の定量はコラーグン代謝に異常をき たす疾患の診断に応用価值が高い7 14)。

今回, 歯周病患者の血清中総ハイプロ量を定量し, 歯 周病における歯肉結合組織及び歯槽骨の破壊との関連を 調べ，その診断価値を検討した。

血中ハイプロの由来としてはコラーゲン分解の他に食 事性に吸収されたハイプロが考えられる。本研究では, 被験者が外来患者であるため完全な食事のコントロール は行なえなかった。採血はゼラチン食を摂取する可能性 の少ない午前中に，食後 3 時間以上経過後に行なうよう 心がけた。普通食(病院食)の場合, 食後 3 時間毎に血中
ハイプロ量の変化を調べても変動しなかったと LeRoy ら ${ }^{11)}$ は報告しているが，一方実験的な高ゼラチン食では 食後尿中血中ハイプロ量が増加し， 2 時間後に最大とな

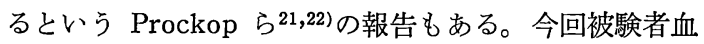
中ハイプロ量は Prockop らの報告にあるような高値 （空腹時に比べゼラチン摂取 2 時間後で約 10 倍に増加） は示しておらず，被験者の食事は LeRoy らの「普通食」 に近いものと考えられる。

ハイプロ定量法は Kivirikko, Prockop ら ${ }^{17,18)}$ の方 法を微量化して行なった。彼らはそのハイプロ定量法が 尿あるいは血清, 組織を試料とした場合にも十分に適用 でき, 試料中の発色妨害物質による影響は $10 \%$ 以下で あると述べている。

コラーゲン合成の盛んな乳児，少年期にはコラーゲン の分解量も多く血中ハイプロ量が増加する ${ }^{11,12)}$ とされて いるが，今回の研究の被験者においては年齢群の間の八 イプロ量に有意の差はなく，対象とした年齢層において 


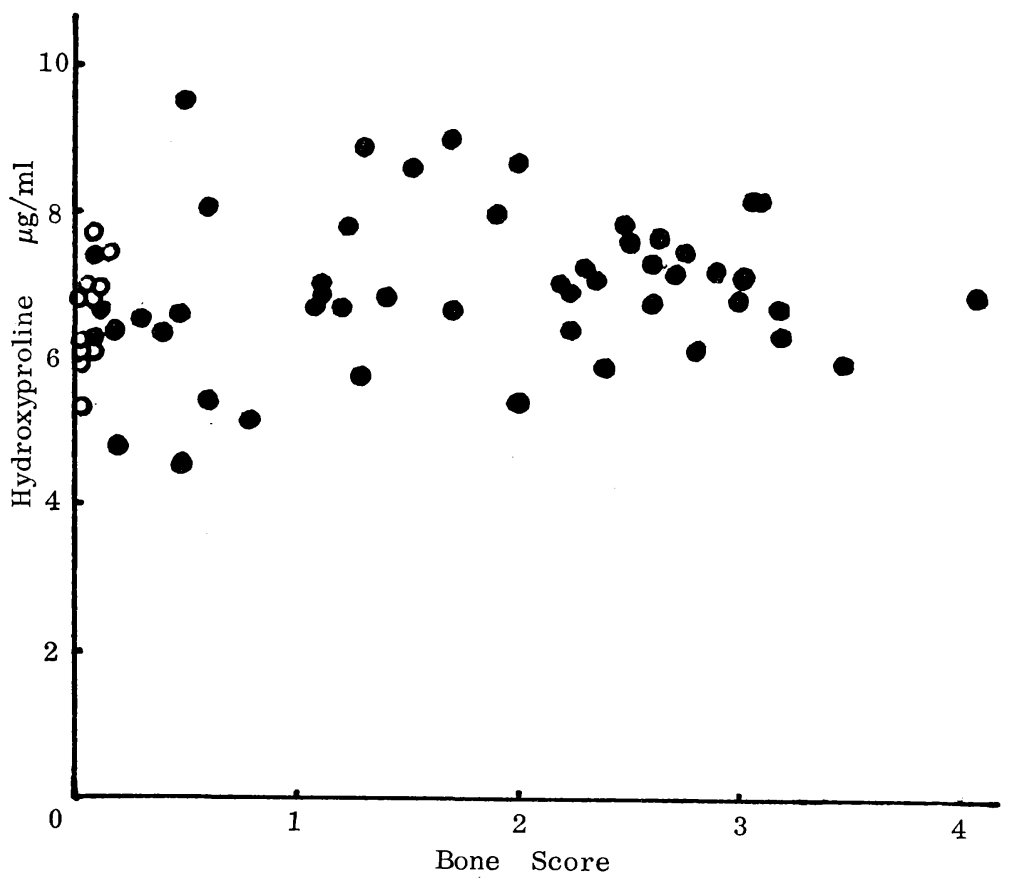

図 4 Correlation between hydroxyproline levels in sera and bone score Patients with periodontal disease

Clinical healthy subjects

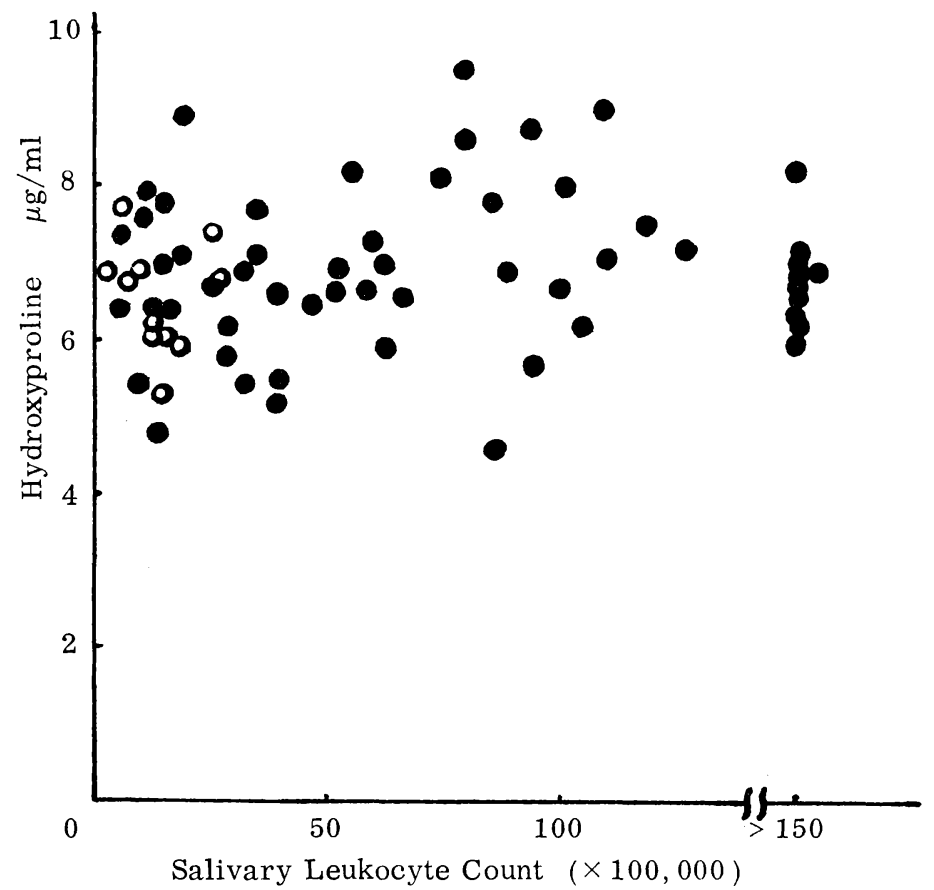

図 5 Correlation between hydroxyproline levels in sera and salivary leukocyte count

Patients with periodontal disease

Clinical healthy subjects 
表 2 Coefflcients of correlation between hydroxyproline levels in sere and periodontal indicies

\begin{tabular}{lccr}
\hline Periodontal indicies Total & \multicolumn{3}{l}{$\begin{array}{l}\text { Clinical } \\
\text { healthy } \\
\text { subjects }\end{array}$} \\
& Patients \\
\hline Gingival-Bone count & 0.18 & 0.38 & 0.09 \\
Gingival score & 0.05 & 0.27 & -0.07 \\
Bone score & 0.24 & $0.70^{*}$ & 0.18 \\
Leukocyte count & 0.12 & -0.13 & 0.08 \\
\hline
\end{tabular}

$* \mathrm{p}<0.02$

は, 血中ハイプロ量に年齡的要因は少ないと考えられ る。

健康者群と患者群の平均值の間に特に有意の差はなか ったが，患者群のハイプロ量の方がやや多い傾向を示し た。

ハイプロ量と歯周病症状との関連においては, Gingival-Bone count, Gingival score, Bone score, 唾 液中白血球数のいずれとも有意の相関は示さなかった。 調べた歯周病指数との間では, Bone score との間の相関 係数が最も大きな值を示した。またハイププロ量と健康 者群における Bone score との間においてだけは有意の 相関が見られた。実際，骨病変においては特に尿中，血 中ハイプロ量が増加するという多くの報告7 14) が見られ る。今回の結果のうち有意の相関が認められたものにつ いては例数が少なく（11名）多少問題はあるが, 血清中 ハイプロ量が歯周病の歯槽骨の吸収を反映している可能 性が考えられこの点については更に検討の必要がある。

今回の実験では, 血清中総ハイプロ量と歯周病指数の いずれとの閒にも有意の相関は示さなかった。この理由 として，第 1 に歯肉結合組織及び歯槽骨を構成するコラ 一ゲン量は身体全体のそれからみると余りにも少量であ り，それらの破壊も慢性であるため，血中のハイプロ量 の変化として検出することが困難であるかも知れない。 第 2 に被験者の食事コントロールの不徹底が挙げられ る。普通食，高ゼラチン食にかかわら年，採血前 24 時 間より絶食状態におくのがより正確な結果が期待できる と考えられる。第 3 に定量法の問題が考えられる。 LeRoy ら ${ }^{23)}$ は, 本研究で使用した Prockop ら ${ }^{18)}$ の方法 は尿, 純粋な蛋白や血中の遊離のハイプロについては信 頼できるが，血液を加水分解したものについては蛋白水 解物中の阻害物質をピロールから完全に分離できず，血 中総ハイプロ量の定量には問題があると報告している。

歯槽骨破壊の指標として血中ハイプロ量の利用のため
には，さらに厳密な条件の設定，鋭敏なハイプロ測定法 が必要であろう。

\section{V. 結 論}

歯周病患者清中総ハイプロ量を定量し，各歯周病指数 との関連を検討し，次の結果を得た。

1. ハイプロ量の平均值を年蹫群により分類したとこ ろ，いずれの年齢群のハイプロ量の間にも有意の差はな かった。また健康者群と患者群に分けて比べるとやや患 者群の方が大きな值を示したが，特に有意の差はなかっ た。

2. Gingival-Bone count, Gingival score, Bone score, および唾液中白血球数とハイプロ量との間に有意 の相関はなった。ただし, 健康者群における Bone score とハイプロ量との間には有意の相関が認められた。また 相関係数の值も他の指数とハイプロ量との間のものに比 べより大きな值を示した。

歯槽骨破壊の指標として血中ハイプロ量を利用するた めには, 今後さらに研究の必要があると考えられる。

\section{文献}

1) 岡本 莫, 河内勝和, 中島朋見, 東 富恵, 北木 マ开子, 花本 裕 : 歯周疾患の口腔診查法; 広大 歯誌, $5: 1-17,1973$.

2) 今川与曹, 石川 純 : 臨床歯周病学 : 東京, 1968, 医歯薬, 34-49.

3) Carranza, F.A. : Glickman's Clinical Periodontology: Philadelphia, 1979, W.B. Saunders Company, 319-351.

4) Grant, D.A., Stern, I.B. and Everett, F.G. : Orban's Periodontics: Saintlouis, 1972, The C.V. Mosby Company, 153-169.

5）内田武志, 菊地貞介, 東 磨美, 吉賀純子, 二宮 順二, 穴村紳一, 岡本 莫 : 歯周病の臨床検査と しての混合唾液中の白血球数と潜血量の検討；月 歯周誌, $18: 406-413,1976$.

6）内田武志，菊地貞介，分村紳一，春間由美子，岡 本 莫：菌周病患者の白血球の Nitroblue tetrazolium 還元試験の検討 ; 甘歯㓮誌, $18: 495-501$, 1976.

7) Prockop, D.J. and Kivirikko, K.I. : Relationship of hydroxyproline excretion in urine to 
collagen metabolism : Annals of Internal Medicine, 66 : 1243-1266, 1967.

8) Prockop, D.J. and Kivirikko, K.I. : Treatise on collagen (Gould, B.S.ed.) : London \& New York, 1968, Academic Press, 215-246.

9) Kivirikko, K.I. : Urinary excretion of hydroxyproline in health and disease: Int. Rev. Connective Tissue Res., $5:$ 93-163, 1970.

10) Laitinen, O. : Clinical applications of urinary hydroxyproline determination: Acta. Med. Scand. suppl., $577: 1-57,1974$.

11) LeRoy, E.C. and Sjoerdsma, A. : Clinical significance of a hydoxyproline-containing protein in human plasma: J. Clin. Invest., $44:$ 914-919, 1965.

12) Laitinen, O., Nikkilä, A. and Kivirikko. K.I. : Hydroxyproline in the serum and urine, Normal values and clinical significance: Acta. Med. Scand., 179 : 275-284, 1966.

13) Raad, W.: The practical importance of determining urinary hydroxyproline excretion : Aerztl. Lab., $21: 282-285,1975$.

14）堺 隆弘：コラーゲン一化学・生物学・医学一 （野田春彦, 永井 裕, 藤本大三郎編) : 東京, 1975, 南江堂, 207-249.

15) Paunio, K.: On the hydroxyproline-containing components in the gingival exudate: $\mathrm{J}$. Periodont. Res., $6: 115-117,1971$.

16）原 耕二, 会田富士子, 田辺秀也, 高橋徳也, 小 林幸男 : 歯周手術後の歯肉組織修復と歯周ポケッ
ト滲出液ハイドロオキシプロリン含有量との関係 について：日歯保誌, $17: 336-345,1974$.

17) Kivirikko, K.I., Laitinen, O. and Prockop, D.J. : Modifications of a specific assay for hydroxyproline in urine : Anal. Biochem., 19 : 249-255, 1967.

18) Prockop, D.J. and Udenfriend. S. : A specific method for the analysis of hydroxyproline in tissue and urine: Anal. Biochem., $1: 228-$ 239, 1960.

19) Dunning, J.M. and Leach, L.B. : GingivalBone count; A method for epidemiological study of periodontal disease: J. Dent. Res., $39:$ 506-513, 1960.

20) Klinkhamer, J.M. : Quantitative evaluation of gingivitis and periodontal disease; $\mathrm{I}$. The orogranulocytic migratory rate : Periodontics, $6: 207-211,1968$.

21) Prockop, D.J., Keiser, H.R. and Sjoerdsma, A.: Gastrointestinal absorption and renal excretion of hydroxyproline peptides : Lancet, $2: 527-528,1962$.

22) Prockop, D.J. and Sjoerdsma, A. : Significance of urinary hydroxyproline in man: J. Clin. Invest., $40: 843-849,1961$.

23) LeRoy, E.C. Kaplan, A., Udenfriend, S. and Sjoerdsma, A. : A hydroxyproline-containing, collagen-like protein in plasma and a procedure for it's assay: J. Biol. Chem., 239: 3350-3356, 1964. 